\title{
Environmental drivers of macrophyte species richness in artificial and natural aquatic water bodies - comparative approach from two central European regions
}

\author{
Richard Hrivnák $^{1 *}$, Judita Kochjarová ${ }^{1,2}$, Helena Ot’ahel'ová ${ }^{1}$, Peter Pal'ove-Balang ${ }^{3}$, \\ Michal Slezák ${ }^{1,4}$ and Peter Slezák ${ }^{5}$ \\ 1 Institute of Botany, Slovak Academy of Sciences, Dúbravská cesta 9, SK-845 23 Bratislava, Slovakia \\ 2 Botanical Garden, Comenius University, Blatnica 315, SK-038 15 Blatnica, Slovakia \\ 3 Institute of Biological and Ecological Sciences, University of P. J. Šafárik, Mánesova 23, SK-040 01 Košice, Slovakia \\ ${ }^{4}$ Department of Biology and Ecology, Faculty of Education, Catholic University, Hrabovská cesta 1, SK-034 01 Ružomberok, \\ Slovakia \\ ${ }^{5}$ Faculty of Medicine, Institute of Simulation and Virtual Medical Education, Comenius University, Špitálska 24, SK-813 72 \\ Bratislava, Slovakia
}

Received 21 March 2014; Accepted 22 July 2014

\begin{abstract}
Species richness of macrophytes of artificial and natural water bodies covering rivers, streams, canals and habitats with standing water was studied in two Central European biogeographical regions, Pannonian and Carpathian, represented by two model areas (the Borská nížina Lowland and the Turčianska Kotlina Basin). We found that: (i) the total number of macrophytes was higher in artificial water bodies compared to natural aquatic habitats in both regions and differences were statistically significant $(P<0.05)$; and (ii) species richness of macrophytes is relatively low in both regions; slightly higher mean number was found in the Pannonian region (3.53) compared with the Carpathian region (3.06). Effects of environmental characteristics on species richness studied by generalized linear model (GLM) showed that explained variances of GLM were similar in both regions. The main drivers of the diversity pattern were those connected with the hydrology of water bodies, such as substrate characteristics and turbidity, less frequent were chemical characteristics, such as water conductivity and N-contents, whereas landscape characteristics manifested the smallest impact.
\end{abstract}

Key words: Aquatic plants / Central Europe / diversity / generalized linear model / species richnessenvironmental relationship

\section{Introduction}

Aquatic macrophytes play an important role in the structure and function of the aquatic ecosystems. They actively affect biochemical cycles, hydrology and sediment dynamics, light availability and provide suitable habitat for animal species (Lacoul and Freedman, 2006; Chambers et al., 2008; Bornette and Puijalon, 2011). Many ecological processes and factors have been used to explain underlying mechanisms of species richness and composition patterns of macrophytes (Lacoul and Freedman, 2006), but their variations have often been attributed to environmental variables integrating mainly

\footnotetext{
*Corresponding author: richard.hrivnak@savba.sk
}

hydrological, substrate and chemical characteristics, nutrients availability and light conditions (Williams et al., 2004; Baattrup-Pedersen et al., 2006; Bornette and Puijalon, 2011).

Previous studies of freshwater biodiversity pointed out the increasing relevance of anthropogenic impact (e.g. Polunin, 2008), leading to worldwide loss of freshwater biodiversity (Dudgeon et al., 2006). Species richness decline resulting from degradation of natural aquatic ecosystems can be partially inhibited by the creation of new, man-made aquatic habitats such as canals, artificial water reservoirs, fishponds or sand/gravel pits. Man-made water bodies are thus relevant localities for diversity preservation of freshwater organisms including macrophytes (Armitage et al., 2003; Williams et al., 2004; Dorotovičová, 2013). 


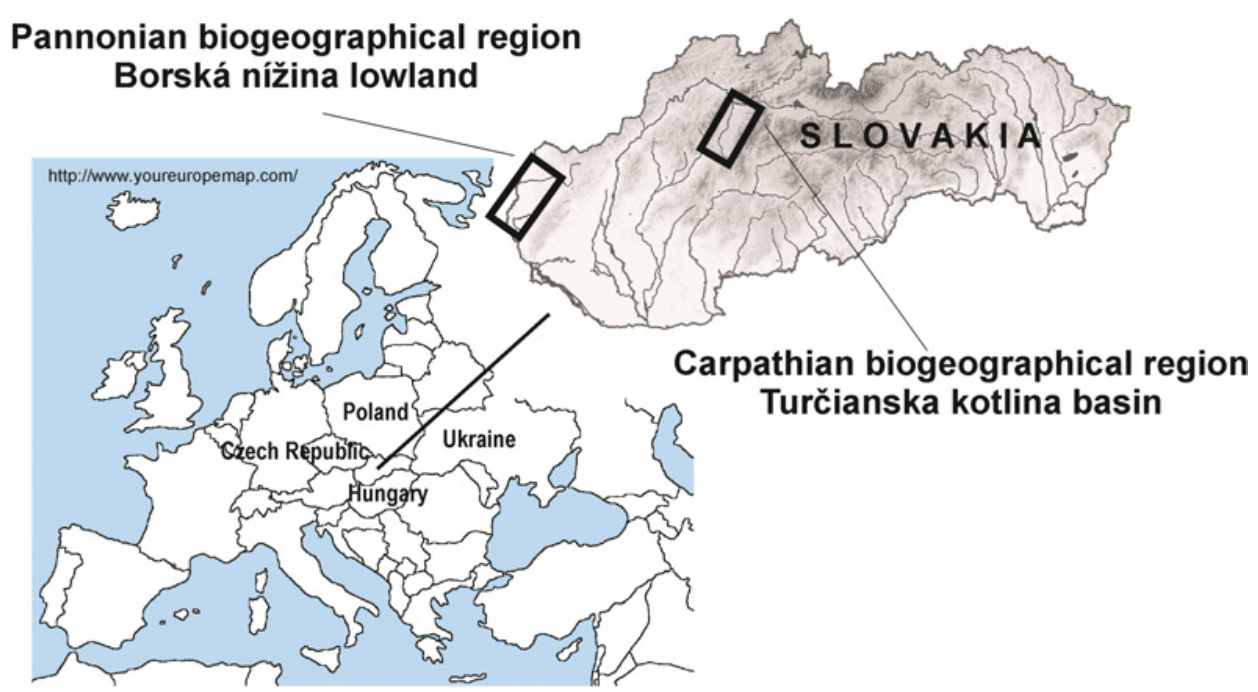

Fig. 1. Map of the studied area.

Macrophyte diversity in freshwater habitats appears to be scale-dependent and varies across different regions, with European peak in the latitudinal range between $40^{\circ}$ and $50^{\circ} \mathrm{N}$ (Lacoul and Freedman, 2006; Chambers et al., 2008; Chappuis et al., 2012). This pattern corresponds well with humidity gradient and accessible water resources, i.e., the highest species richness observed in Western and Northern Europe having in general more humid climate is gradually reduced towards more continental Central European countries including Slovakia (Chappuis et al., 2012). This territory represents a contact area of the Carpathian and Pannonian regions that are characterized by distinctive environmental conditions. The southern part of Slovakia belongs to the Pannonian region, whereas the central and northern part to the Carpathian region. Although they share a certain proportion of common plant species groups, there are conspicuous floristic (including macrophytes) differences between them (Futák, 1972; Hrivnák et al., 2013).

If environmental peculiarities and the origin of study sites are taken into account, we expected differences in species richness between regions. The systematic and longterm research of aquatic ecosystems in Slovakia in the past decades (for reviews see Hrivnák et al., 2007; Baláži et al., 2011) indicates that species richness may be higher in artificial than in natural aquatic habitats. This assumption is in accordance with the main outcomes of some earlier studies which were performed in man-made aquatic habitats across the whole Europe. They suggest a relatively high plant species richness of ponds (Biggs et al., 2005; Davies et al., 2008) and comparable or even higher species richness of canals compared with natural waters (Dorotovičová, 2013). Based on this evidence, the aims of our study were: (1) to detect potential differences between natural and artificial aquatic habitats in species richness of macrophytes and environmental variables in two distinct regions; and (2) to find environmental drivers responsible for variation in species richness within both regions.

\section{Study area}

Species richness of macrophytes was studied in the Pannonian and Carpathian regions in Slovakia where two representative model areas were selected (Fig. 1): the Borská nížina Lowland $\left(16^{\circ} 50^{\prime}-17^{\circ} 19^{\prime} \mathrm{E}, 48^{\circ} 13^{\prime}-48^{\circ} 32^{\prime} \mathrm{N}\right)$ and the Turčianska Kotlina Basin $\left(18^{\circ} 45^{\prime}-19^{\circ} 6^{\prime} \mathrm{E}, 48^{\circ} 50^{\prime}-\right.$ $\left.49^{\circ} 7^{\prime} \mathrm{N}\right)$. Both areas showed the similar landscape structure with a mosaic of arable fields and forests, but at the same time, they differed in altitudinal gradients and climatic conditions (median altitude of the Borská nížina Lowland is $152 \mathrm{~m}$ and that of the Turčianska Kotlina Basin is $426 \mathrm{~m}$ ). The Pannonian climate with warmer and drier vegetation season is more pronounced in the southern part of the study area (the Borská nížina Lowland; mean July temperature is $18-20^{\circ} \mathrm{C}$ and mean annual precipitation $500-600 \mathrm{~mm}$ ), whereas a more humid Carpathian climate affects its northern part (the Turčianska Kotlina Basin; $14-16^{\circ} \mathrm{C}, 800-900$ mm).

\section{Methods}

\section{Field sampling and laboratory analyses}

We studied four main types of aquatic water bodies (rivers, streams, canals and ponds) including those of natural (rivers, streams, river oxbows and watered terrain depression such as natural pond-types) and artificial (drainage and irrigation canals, water reservoirs, sand or gravel pits such as artificial pond-types) origin (Williams et al., 2004; Hrivnák et al., 2013). The present habitat stratification (i.e., 20 sampling sites of each abovementioned water bodies per region) allowed us to cover a broad range of geological and geomorphological conditions. This sampling design led to compilation of data matrix with 160 sites (2 regions $\times 4$ water body types $\times 20$ sampling sites). To eliminate potential effect of 
Table 1. Basic characteristic of the studied environmental variables and differences between natural and artificial aquatic habitats in both biogeographical regions.

\begin{tabular}{|c|c|c|c|c|c|c|}
\hline \multirow[b]{2}{*}{ Environmental variables } & \multicolumn{2}{|c|}{ Pannonian region } & \multirow[b]{2}{*}{$\begin{array}{c}\mathrm{M}-\mathrm{W} \\
P \text { value }\end{array}$} & \multicolumn{2}{|c|}{ Carpathian region } & \multirow[b]{2}{*}{$\begin{array}{c}\mathrm{M}-\mathrm{W} \\
P \text { value }\end{array}$} \\
\hline & $\begin{array}{c}\text { Artificial } \\
\text { Mean }( \pm \mathrm{SD}) \\
n=33\end{array}$ & $\begin{array}{c}\text { Natural } \\
\text { Mean }( \pm \mathrm{SD}) \\
n=45\end{array}$ & & $\begin{array}{c}\text { Artificial } \\
\text { Mean }( \pm \mathrm{SD}) \\
n=32\end{array}$ & $\begin{array}{c}\text { Natural } \\
\text { Mean }( \pm \mathrm{SD}) \\
n=46\end{array}$ & \\
\hline \multicolumn{7}{|l|}{$\overline{\text { Quantitative variables }}$} \\
\hline Mean depth of water $(\mathrm{cm})$ & $107.92 \pm 79.37$ & $78.82 \pm 46.34$ & ns & $82.58 \pm 71.10$ & $38.47 \pm 26.88$ & $*$ \\
\hline Fine substrate $(\%)$ & $47.58 \pm 41.69$ & $38.22 \pm 45.89$ & ns & $57.19 \pm 34.57$ & $16.74 \pm 32.32$ & $* * *$ \\
\hline Sand substrate $(\%)$ & $33.94 \pm 40.92$ & $21.11 \pm 35.82$ & ns & $13.75 \pm 23.79$ & $6.52 \pm 12.33$ & ns \\
\hline Shading $(\%)$ & $25.30 \pm 36.11$ & $39.47 \pm 39.65$ & ns & $40.09 \pm 40.71$ & $52.24 \pm 37.95$ & ns \\
\hline Forests $(\%)$ & $26.98 \pm 36.99$ & $25.58 \pm 32.30$ & ns & $22.19 \pm 27.29$ & $22.17 \pm 25.79$ & ns \\
\hline Wetlands (\%) & $11.17 \pm 28.31$ & $8.13 \pm 18.03$ & ns & $6.34 \pm 14.41$ & $4.37 \pm 12.45$ & ns \\
\hline Meadows (\%) & $16.39 \pm 23.92$ & $27.69 \pm 31.68$ & ns & $37.81 \pm 32.65$ & $36.52 \pm 31.52$ & ns \\
\hline Fields $(\%)$ & $35.67 \pm 35.99$ & $25.97 \pm 33.74$ & ns & $17.91 \pm 25.51$ & $18.15 \pm 27.88$ & ns \\
\hline Artificial (\%) & $7.79 \pm 18.37$ & $9.63 \pm 19.58$ & ns & $11.69 \pm 21.96$ & $17.04 \pm 26.53$ & ns \\
\hline Water nitrate $\left(\mathrm{mg} . \mathrm{L}^{-1}\right)$ & $1.17 \pm 1.61$ & $2.55 \pm 2.33$ & $* *$ & $2.09 \pm 1.89$ & $2.94 \pm 1.47$ & $*$ \\
\hline Water nitrite $\left(\mathrm{mg} . \mathrm{L}^{-1}\right)$ & $0.11 \pm 0.18$ & $0.09 \pm 0.12$ & ns & $0.14 \pm 0.15$ & $0.15 \pm 0.15$ & ns \\
\hline Water phosphate (mg. $\left.\mathrm{L}^{-1}\right)$ & $0.32 \pm 0.38$ & $0.29 \pm 0.38$ & ns & $0.17 \pm 0.24$ & $0.22 \pm 0.31$ & ns \\
\hline Substrate $\mathrm{pH}$ & $7.23 \pm 0.86$ & $7.43 \pm 0.68$ & ns & $7.64 \pm 0.35$ & $7.80 \pm 0.47$ & $*$ \\
\hline Substrate conductivity $\left(\mu \mathrm{S} . \mathrm{cm}^{-1}\right)$ & $969.15 \pm 761.01$ & $756.70 \pm 651.19$ & ns & $939.40 \pm 845.14$ & $584.35 \pm 433.06$ & $*$ \\
\hline Substrate ammonia $\left(\mu \mathrm{g} \cdot \mathrm{g}^{-1}\right)$ & $24.36 \pm 29.85$ & $22.43 \pm 25.93$ & ns & $39.20 \pm 21.95$ & $35.32 \pm 20.80$ & ns \\
\hline Substrate nitrate $\left(\mu \mathrm{g} \cdot \mathrm{g}^{-1}\right)$ & $6.69 \pm 10.83$ & $9.55 \pm 12.32$ & ns & $1.33 \pm 2.06$ & $3.01 \pm 4.06$ & ns \\
\hline Substrate nitrite $\left(\mu \mathrm{g} . \mathrm{g}^{-1}\right)$ & $0.78 \pm 0.99$ & $1.29 \pm 3.21$ & ns & $0.48 \pm 0.61$ & $0.89 \pm 1.77$ & ns \\
\hline Substrate phosphate $\left(\mu \mathrm{g} \cdot \mathrm{g}^{-1}\right)$ & $102.62 \pm 71.46$ & $120.03 \pm 66.89$ & ns & $69.29 \pm 60.92$ & $87.61 \pm 58.87$ & $*$ \\
\hline \multicolumn{7}{|l|}{ Categorical variables } \\
\hline Water regime & $1.03 \pm 0.17$ & $1.13 \pm 0.50$ & ns & $1.58 \pm 0.72$ & $1.20 \pm 0.50$ & ns \\
\hline Flow velocity & $1.67 \pm 0.65$ & $2.42 \pm 0.78$ & $* * *$ & $1.78 \pm 0.83$ & $2.91 \pm 0.84$ & $*$ \\
\hline
\end{tabular}

Significance of the Mann-Whitney $U$ test $(\mathrm{M}-\mathrm{W}): \mathrm{ns}=$ non-significant; $* P<0.05 ; * * P<0.01 ; * * * P<0.001$.

vegetation seasonality on the species richness pattern, a half of sampling sites were studied in the early summer (June) and the second part at the end of summer (August and September) in 2011. A total plant species list of macrophytes (Charophytes, bryophytes and vascular plants including true aquatic and marsh plants; Janauer and Dokulil, 2006) was done for each sampling site with uniform size of $100 \mathrm{~m}^{2}$ by walking and/or by boat. Sampling area was determined as length $\times$ width of water course in lotic habitats, whereas a triangular design (the apex at the middle of the water body and the base along the margin edge) was applied in lentic habitats. Small ponds were thus excluded from potential studied sites. Nomenclature of plant species is in accordance with the checklist of Marhold and Hindák (1998), the categories of threat are classified according to Baláž et al. (2001).

The following environmental variables were measured and/or scored on each sampling site (Table 1; see Hrivnák et al., 2013 for the methodological details). Shading by woody vegetation as the percentage cover of tree and shrub layers on the banks, type of water regime (from 1 - permanently waterlogged to 4 -dried every year; W_regime; sensu Williams et al., 2004; Hrivnák et al.,
2013), turbidity (from 1 - clear to 4 - turbid; sensu Williams et al., 2004; Hrivnák et al., 2013) and percentage proportion of contact habitats (forests, wetlands, meadows, fields, artificial) up to distance of $100 \mathrm{~m}$ from the sampling site were visually estimated in the field. Mean depth of water was derived from ten random measurements on the each site. The particle-size distribution of bottom substrate type (fine material consisting of inorganic and organic materials, sand, gravel, coarse $=$ rock and large artificial material) and flow velocity ( 1 - stagnant, 2 - low flow, 3 - medium flow and 4 - high flow) were assessed according to recommendations of Janauer (2003). In order to partially reduce natural temporal variability of several water-related variables, water $\mathrm{pH}$, conductivity and temperature were measured with the CyberScan PC 650 equipment in all sampling sites during 1 week at the end of summer.

Water samples were taken from all sampling sites during the same time of the summer. They were quickly frozen at $-18{ }^{\circ} \mathrm{C}$ and used for chemical analyses of ammonia, nitrite, nitrate and phosphate contents. Ammonia content was determined by the Nessler's method using the Hanna Instruments standard kit 
(HI 93715). Nitrite content was determined spectrophotometrically at $\lambda=540 \mathrm{~nm}$, after diazotation with 40 g. $\mathrm{L}^{-1}$ sulfanilamide and 2 g. $\mathrm{L}^{-1} N$-(1-naphthyl)-ethylenediamine dihydrochloride in $10 \% \mathrm{H}_{3} \mathrm{PO}_{4}$. Nitrate plus nitrite level in the samples was measured by the same method except that the samples were reduced with 1.4 g.L $\mathrm{L}^{-1}$ hydrazinsulphate, 7.5 g.L ${ }^{-1} \mathrm{CuSO}_{4}$ and then neutralized adding 3 g. $\mathrm{L}^{-1} \mathrm{NaOH}$ prior to diazotation. The nitrate content was then calculated as the difference in the absorbance of the same sample with and without reduction. Phosphate content was analysed spectrophotometrically according to the modified method described by Rodriguez et al. (1994), measuring the absorbance of the samples at $\lambda=720 \mathrm{~nm}$, after derivatization with ammonium-molybdate reagent containing $0.1 \mathrm{M}$ sulfamic acid, $0.01 \mathrm{M}$ ammonium molybdate, $0.1 \mathrm{M}$ potassium antimonyl oxide tartarate and $0.1 \mathrm{M}$ ascorbic acid (see also Hrivnák et al., 2010).

Sediment samples were randomly collected in three places from the bottom of each sampling site and mixed to form a single sample per site in order to reduce substrate heterogeneity. All samples were collected during 1 week at the end of summer. They were dried at laboratory temperature, crushed and passed through a $2 \mathrm{~mm}$ sieve. Substrate $\mathrm{pH}$ and conductivity were determined in distilled water using the CyberScan PC 650 multiparameter device (substrate/water ratio $=1: 2.5$ ). Nitrate, nitrite and ammonia content was determined in the samples extracted $2 \mathrm{~h}$ with $1 \mathrm{M} \mathrm{KCl}$ and centrifuged for $10 \mathrm{~min}$. at $2000 \mathrm{~g}$, by the same methods as that used for water analyses. For the determination of extractable phosphate, samples were extracted for $2 \mathrm{~h}$ using Mehlich 3 extraction solution (0.2 $\mathrm{M}$ acetic acid, $0.25 \mathrm{M} \mathrm{NH}_{4} \mathrm{NO}_{3}, 0.015 \mathrm{M} \mathrm{NH}_{4} \mathrm{~F}$, $0.013 \mathrm{M} \mathrm{HNO}_{3}$ and $0.001 \mathrm{M}$ EDTA). Phosphate was determined by the ammonium-molybdate method as described above (Hrivnák et al., 2013).

\section{Statistical approach}

Four sampling sites with incomplete list of environmental variables were excluded prior to the analyses. They were divided according to two criteria: (i) man-made (Artificial) and natural (Natural) habitats based on origin (subset i), and (ii) man-made habitats (Artificial) and recent natural habitats without any signs of human-caused modification of their natural character (Recent natural; subset ii). Statistical differences in environmental variables between artificial and natural habitats within both regions (subset i) and in species richness (subsets $\mathrm{i}$ and ii) were tested by the Mann-Whitney $U$ test at 5\% level of significance. Variation of plant species richness was modelled using the generalized linear model (GLM; McCullagh and Nelder, 1989). Since the dependent variables represent count data, Poisson error distribution and logarithmic link function were used in model specifications. Three models were created: (i) the null model involving only the dependent variable without any predictors (explanatory variables); (ii) the full model with all explanatory variables; and (iii) the minimal adequate model that explains the highest proportion of variation using minimum number of explanatory variables. The minimal model was calculated using backward stepwise selection based on the Akaike information criterion (AIC; Akaike, 1973), following the recommendation of Johnson and Omland (2004). Influential data points were determined using Cook's distance. Statistical significance of each variable in the minimal model was tested by the $\chi^{2}$ statistic and differences between the full and minimal GLM models by the $F$ test. The adjusted $D^{2}\left(D_{\text {adj }}^{2}\right)$ was calculated as a measure of goodness-of-fit for the minimal GLM (Guisan and Zimmermann, 2000). Multicollinearity was recorded for both final GLMs using the variance inflation factor according to Chatterjee et al. (2000). Habitat origin entered the model as binary variable in order to test its relevance for species richness of macrophytes. All statistical analyses were performed in the STATISTICA software (StatSoft, 2001) and the R software, version 3.0.2 (R Development Core Team 2013).

\section{Results}

\section{Species richness}

Altogether 72 macrophyte taxa were found in both studied regions: vascular plants represented $86.1 \%$, bryophytes $9.7 \%$ and macroscopic algae (genera Chara and Nitella) 4.2\% (Supplementary Appendix 1, available at: www.limnology-journal.org). Although the species richness of macrophytes was generally low and varied only slightly between regions, higher mean number was found in the Pannonian region (3.53) than in the Carpathian region (3.06) including both artificial and natural habitats. A similar pattern was also found when only artificial and natural habitats were taken into account (Table 2). Artificial water bodies showed similar total species number in both regions (37 versus 39 in the Pannonian and Carpathian regions, respectively), whereas the total species number of natural water bodies was higher in the Pannonian region (42 versus 31; Supplementary Appendix 1). Although statistically significant differences $(P<0.05)$ in species richness of artificial and natural habitats were found in both regions (Table 2; Fig. 2(A) and (C)), artificial and recent natural habitats significantly differed only in the Carpathian region (Table 2; Fig. 2(B) and (D)).

\section{Environmental variables}

In the Pannonian region, higher mean values were detected in natural habitats for the portion of coarse substrate on the bottom, flow velocity and nitrate content in water. In the Carpathian region, higher mean values were found within natural habitats in the case of the portion of coarse substrate on the bottom, water and soil reaction, nitrate content in water, phosphate content in 
Table 2. Comparison of the species richness of artificial and natural aquatic habitats in two distinct regions.

\begin{tabular}{|c|c|c|c|c|c|c|c|}
\hline \multirow[b]{3}{*}{ Habitat } & \multicolumn{2}{|c|}{ Mean (Min-Max) } & \multirow[b]{3}{*}{ Recent natural } & \multicolumn{2}{|c|}{ Mann-Whitney $U$ test } & \multirow{2}{*}{\multicolumn{2}{|c|}{ Artificial versus Recent natural }} \\
\hline & \multirow[b]{2}{*}{ Artificial } & \multirow[b]{2}{*}{ Natural } & & Artificial & Natural & & \\
\hline & & & & $Z$ value & $P$ value & $Z$ value & $P$ value \\
\hline$\overline{\text { Pannonian region }}$ & & & & & & & \\
\hline Number of cases & 33 & 45 & 18 & & & & \\
\hline Number of species & $4.3(0-12)$ & $2.96(0-14)$ & $3.39(0-8)$ & 2.276 & 0.02 & 0.956 & 0.34 \\
\hline Carpathian region & & & & & & & \\
\hline Number of cases & 32 & 46 & 32 & . & . & . & . \\
\hline Number of species & $3.91(0-10)$ & $2.48(0-9)$ & $2.56(0-9)$ & 2.529 & 0.01 & 2.276 & 0.02 \\
\hline
\end{tabular}

\section{(A)}

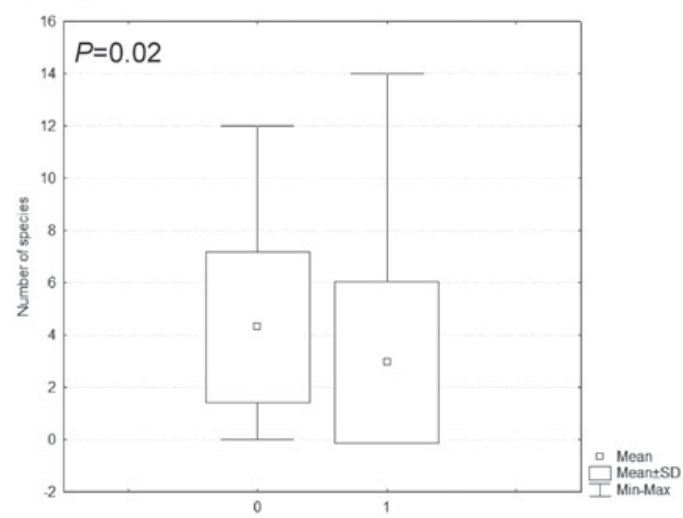

(C)

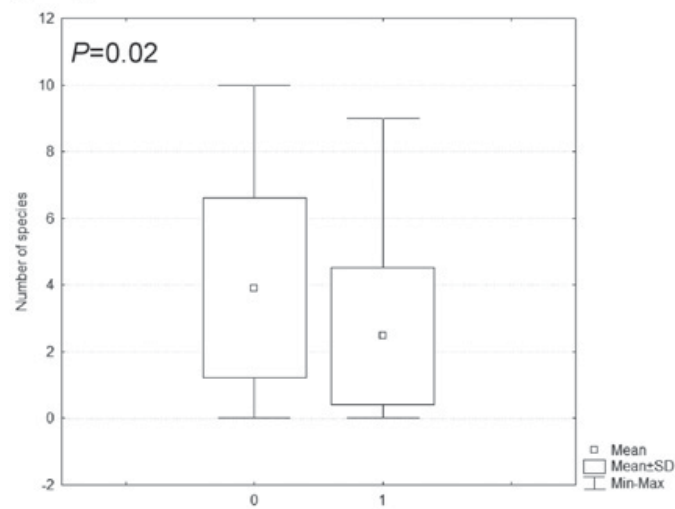

(B)

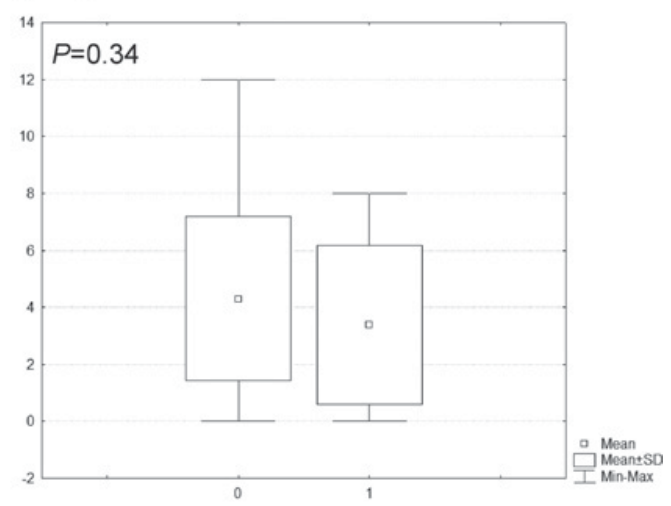

(D)

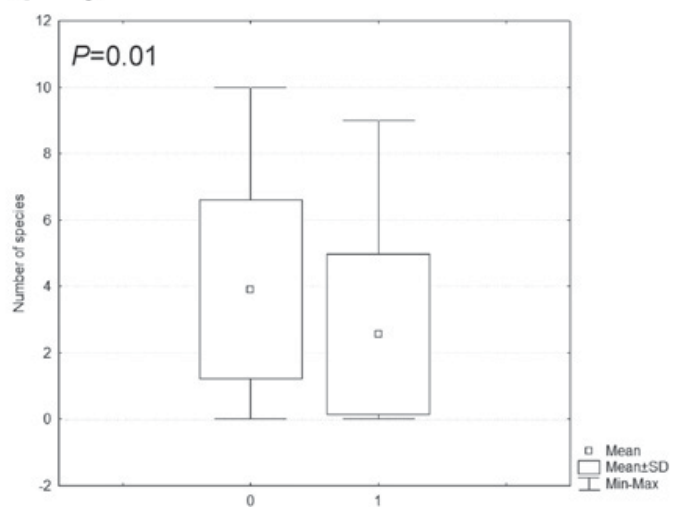

Fig. 2. The box-plots of macrophyte species richness in the Pannonian (A and B) and Carpathian $(C$ and $D)$ regions. $0=$ artificial aquatic habitats; $1=$ natural aquatic habitats, 1 in $\mathrm{A}$ and $\mathrm{C}=$ natural habitats and 1 in $\mathrm{B}$ and $\mathrm{D}=\operatorname{recent}$ natural habitats; $P=$ level of significance (see the Methods section).

soil and flow velocity. In artificial habitats, water depth, portion of fine substrate in bottom and soil conductivity had higher mean values. In spite of considerable variation in values of environmental factors, only three variables (water nitrate, coarse substrate on the bottom and flow velocity) showed significant differences between artificial and natural habitats within regions (Table 1 ).

\section{Effect of environmental variables on species richness}

The GLM identified that the total explained variation in the species richness of macrophytes was similar in both Pannonian (42.3\%) and Carpathian (44.7\%) regions (Table 3). Differences between full and minimal GLM models were statistically non-significant. Seven variables were retained in each model; six with negative and one with positive influences on species richness in the Pannonian region and two with negative and five with positive influences on species richness in the Carpathian region (Table 3 ). Species richness had a positive relationship with water nitrite and negative with substrate characteristics (sand and coarse substrates), shading and water depth, nitrate and turbidity in the Pannonian region. Except for coarse substrate on the bottom, all substrate 
Table 3. Summary of the GLM minimal model for the macrophyte species richness. Variables were added sequentially (first to last; $\left.{ }^{*} P<0.05,{ }^{*} P<0.01, * * * P<0.001\right)$. The plus/minus symbols refer to the regression coefficient of the respective variable in the model.

\begin{tabular}{|c|c|c|c|c|c|}
\hline Region & Variables & Deviance reduction & $P\left(\chi^{2}\right)$ & $D^{2}$ adj & $\begin{array}{l}\text { Difference between full } \\
\text { and minimal GLM } P\left(\chi^{2}\right)\end{array}$ \\
\hline \multicolumn{6}{|c|}{$\overline{\text { Pannonian }}$} \\
\hline & - Coarse substrate & 34.70 & $* * *$ & 0.423 & 0.596 \\
\hline & - Shading & 23.60 & $* * *$ & & \\
\hline & - Water nitrate & 7.81 & $* *$ & & \\
\hline & + Water nitrite & 10.20 & $* *$ & & \\
\hline & - Mean depth of water & 11.50 & $* * *$ & & \\
\hline & - Sand substrate & 5.34 & $*$ & & \\
\hline & - Turbidity & 9.79 & $* *$ & & \\
\hline \multicolumn{6}{|c|}{ Carpathian } \\
\hline & + Water regime & 30.40 & $* * *$ & 0.447 & 0.625 \\
\hline & + Fine substrate & 5.56 & $*$ & & \\
\hline & - Sand substrate & 9.55 & $* *$ & & \\
\hline & + Gravel substrate & 10.00 & $* *$ & & \\
\hline & - Turbidity & 5.54 & $*$ & & \\
\hline & + Water temperature & 4.13 & $*$ & & \\
\hline & + Water conductivity & 6.09 & $*$ & & \\
\hline
\end{tabular}

Null deviance: 220.01 and 145.11 in Pannonian and Carpathian regions, respectively.

characteristics were also important in the Carpathian region. Water regime, water temperature, water conductivity and turbidity were also found to be significant in the Carpathian region (Table 3 ). The origin of aquatic habitats was not found as a predictor in species richness of macrophytes.

Coarse substrate on the bottom and water nitrate, which significantly differed between natural and artificial aquatic habitats, were simultaneously included into the GLM model in the Pannonian region, but only content of fine substrate material in the Carpathian region (Tables 1 and 3).

\section{Discussion}

Species richness of macrophytes was higher in artificial than natural water bodies under study. Man-made water bodies such as pits, artificial water reservoirs or canals provide also suitable environmental conditions for potential establishment and growth of macrophytes. They can re-establish natural biotopes, which are continuously adversely modified or even destroyed by various anthropogenic events. The important role of ponds (they encompass both man-made and natural water bodies) in maintaining aquatic biodiversity and their relatively high species richness was already proved several times (Williams et al., 2004; Biggs et al., 2005; Davies et al., 2008). Specific artificial pond types (e.g., farmland ponds, watered gravel, sand or clay pits) can create sufficient conditions for macrophytes and their species diversity can be similar to natural ones (Linton and Goulder, 2000; Markwell and Fellows, 2008). In addition to the origin of a water body, species diversity is also controlled by a set of another factors, including the age of water body, management practices and nutrient content (Linton and Goulder, 2000; Mari et al., 2010). An analogous situation was observed in canals where diverse species richness patterns (Armitage et al., 2003; Williams et al., 2004) are closely associated with the hydrological mode, utilization, land use or human impacts. The present study further reinforces the theory that canals as man-made aquatic habitats are able to host a number of macrophytes including highly threatened plant species (Sipos et al., 2003; Ot'ahel'ová et al., 2007; Dorotovičová, 2013). On the other hand, invasions by alien plant species belong to frequently discussed biological phenomenon, which may enrich the overall floristic spectrum in terrestrial and freshwater ecosystems (Lambdon et al., 2008; Hejda et al., 2009; Aguiar and Ferreira, 2013). However, we do not suppose this process to be relevant in our case, as the only non-native species in Europe Elodea canadensis was found in the studied water bodies with similar abundances in both artificial and natural habitats.

Although a higher macrophyte species richness of artificial water bodies in Slovakia must be interpreted with reference to their species composition, there might be several mutually non-exclusive mechanisms responsible for this pattern. Firstly, aquatic habitats with running water, which are in general species-poorer compared with those having standing water (Davies et al., 2008), were more abundant in natural habitats of Slovakia. Secondly, extensive management practices accompanied by natural disturbance events lead to maintenance of intermediate plant standing crop promoting the survival of more plant species (Willby et al., 2001). The major part of artificial water bodies under our study has been affected only slightly by human activities in the past decades and environmental conditions are similar as in the case of natural water bodies. 
Except for sand on the bottom and water turbidity, influential environmental factors for the species richness variation differed between regions. The crucial role plays especially hydrological characteristics (e.g., various types of the bottom substrate, water regime, depth and turbidity). Unlike hydrological and physical-chemical variables, landscape-related characteristics were significant only for the Pannonian region. In general, aquatic plants are primarily influenced by factors inherent to the limnology of water bodies, including those related to such physical attributes as geology, topography, sediment, climate and hydrology (Lacoul and Freedman, 2006). Our results are thus in accordance with the predominant trend.

Most of the identified environmental drivers for macrophyte diversity have already been determined in previous studies (e.g., Lacoul and Freedman, 2006; Bornette and Puijalon, 2011). Negative impact of high turbidity is usually attributed to the lower accessibility of light for phototrophic macrophytes (Lacoul and Freedman, 2006). Inconsistent influences of the coarse bottom substrate on species richness most likely result from different eco-physiological preferences of main plant functional groups. The portion of the coarse bottom substrate showed a negative and a positive effect in the Pannonian and Carpathian regions, respectively. The same pattern has formerly been reported by BaattrupPedersen et al. (2006) in streams. They observed a shift from the predominance of species-poor shallow mountain streams to richer lowland streams, i.e., from moss- and liverwort-dominated communities in small-sized to communities dominated by vascular plants in the mediumsized. Although the coarse substrate material does not support higher numbers of vascular plants, it positively affects bryophyte species richness especially in mountain streams (Hrivnák et al., 2010; O'Hare et al., 2011; Ceschin et al., 2012). Thus, in the case of lowland streams with major occurrence of vascular plant species, the coarse substrate affects richness negatively, while the gravel and rocky substrates in mountain streams with prevailing abundance of bryophytes provides suitable conditions. Moreover, bryophytes that occurred much more often in the Carpathian region (see Appendix 1) are better adapted to higher shading by woody species. On the other hand, the sand substrate had similar negative effects in both regions. Sand bottom substrate is not an optimal surface type for macrophyte existence because of its instability to hydrological disturbances (Lacoul and Freedman, 2006).

\section{Conclusion}

Our study showed that the artificial aquatic habitats (i) have higher diversity compared with natural water bodies in different regions typical for the Central European landscape; and (ii) these man-made habitats can provide appropriate ecological conditions for the survival of macrophytes. However, preservation of natural water bodies has crucial role from the point of view of biodiversity, landscape variability, and natural and cultural heritage conservations. The main drivers of the diversity pattern were those connected with the hydrology of water bodies, such as substrate characteristics and turbidity, less frequent were chemical characteristics, such as water conductivity and N-contents, while landscape characteristics manifested the smallest impact. The origin of water bodies did not prove to be a predictor of the species diversity of macrophytes.

Acknowledgements. We thank our colleagues and students, A. Čaja, Š. Horáčková, I. Malina, D. Treplanová for their help in the field and the laboratory. We are also grateful to four anonymous reviewers that helped to improve our manuscript. This study was supported by the VEGA Grant Agency (grant no. 2/0004/11) and the Slovak Research and Development Agency under the contract no. APVV-0059-11.

\section{References}

Aguiar F.C.F. and Ferreira M.T., 2013. Plant invasions in the rivers of the Iberian Peninsula, south-western Europe: a review. Plant Biosyst., 147, 1107-1119.

Akaike H., 1973. Information theory as an extension of the maximum likelihood principle. In: Petrov B.N. and Csaki F. (eds.), Second International Symposium on Information Theory, Akadémiai Kiadó, Budapest, 267-281.

Armitage P.D., Szoszkiewicz K., Blackburn J.H. and Nesbitt I., 2003. Ditch communities: a major contributor to floodplain biodiversity. Aquat. Conserv.: Mar. Freshwat. Ecosyst., 13, 165-185.

Baattrup-Pedersen A., Szoszkiewicz K., Nijboer R., O'Hare M. and Ferreira T., 2006. Macrophyte communities in unimpacted European streams: variability in assemblage patterns, abundance and diversity. Hydrobiologia, 566, 179-196.

Baláž D., Marhold K., Urban P., 2001. Červený zoznam rastlín a živočíchov Slovenska. Ochr. Prír., 20 (Suppl.), 1-160.

Baláži P., Tóthová L., Ot’ahel'ová H., Hrivnák R. and Mišíková K., 2011. Zoznam zistených taxónov na monitorovaných lokalitách vodných útvarov povrchových vôd Slovenska. Čast' 3 vodné makrofyty. Acta Environ. Univ. Comenianae, $19,5-89$.

Biggs J., Williams P., Whitfield M., Nicolet P. and Weatherby A., 2005. 15 years of ponds assessment in Britain: results and lessons learned from the work of Pond Conservation. Aquat. Conserv., 15, 693-714.

Bornette G. and Puijalon S., 2011. Response of aquatic plants to abiotic factors: a review. Aquat. Sci., 73, 1-14.

Ceschin S., Bisceglie S. and Aleffi M., 2012. Contribution to the knowledge of the bryoflora of running waters of Central Italy. Plant Biosyst., 146, 622-627.

Chambers P.A., Lacoul P., Murphy K.J. and Thomaz S.M., 2008. Global diversity of aquatic macrophytes in freshwater. Hydrobiologia, 595, 9-26.

Chappuis E., Ballesteros E. and Gacia E., 2012. Distribution and richness of aquatic plants across Europe and Mediterranean countries: patterns, environmental driving factors and comparison with total plant richness. J. Veg. Sci., 23, 985-997. 
Chatterjee S., Hardi A.S. and Price B., 2000. Regression Analysis by Example, Willey, New York, 384 p.

Davies B., Biggs J., Williams P., Whitfield M., Nicolet P., Sear D., Bray S. and Maund S., 2008. Comparative biodiversity of aquatic habitats in the European agricultural landscapes. Agric. Ecosyst. Environ., 125, 1-8.

Dorotovičová C., 2013. Man-made canals as a hotspot of aquatic macrophyte biodiversity in Slovakia. Limnologica, 43, 277-287.

Dudgeon D., Arthington A.H., Gessner M.O., Kawabata Z-I., Knowler D.J., Lévêque C., Naiman R.J., Prieur-Richard -H., Soto D., Stiassny M.L.J. and Sullivan C.A., 2006. Freshwater biodiversity: importance, threats status and conservation challenges. Biol. Rev., 81, 163-182.

Futák J., 1972. Fytogeografický prehl'ad Slovenska. In: Lukniš M. (ed.), Slovensko 2, Príroda, Obzor, Bratislava, 431-482.

Guisan A. and Zimmermann N.E., 2000. Predictive habitat distribution models in ecology. Ecol. Model., 135, 147-186.

Hejda M., Pyšek P. and Jarošík V., 2009. Impact of invasive plants on the species richness, diversity and composition of invaded communities. J. Ecol., 97, 393-403.

Hrivnák R., Ot’ahel’ová H. and Valachovič M., 2007. Vodná a močiarna vegetácia na Slovensku - súčasné výsledky výskumu a pohl'ad spät'. Zpr. Čs. Bot. Společ., 42, Materiály 22, 29-38.

Hrivnák R., Ot’ahel’ová H., Valachovič M., Pal'ove-Balang P. and Kubinská A., 2010. Effect of environmental variables on the aquatic macrophyte composition pattern in streams: a case study from Slovakia. Fundam. Appl. Limnol., 177, $115-124$.

Hrivnák R., Ot’ahel’ová H., Kochjarová J. and Palove-Balang P., 2013. Effect of environmental conditions on species composition of macrophytes in two distinct biogeographical regions of Central Europe. Knowl. Manag. Aquat. Ecosyst., $09,1-15$.

Janauer G.A., 2003. Methods. In: Janauer G.A., Hale P. and Sweeting R. (eds.), Macrophyte Inventory of the River Danube: A Pilot Study. Arch. Hydrobiol., 147 (Suppl.), Large Rivers, 14, 9-16.

Janauer G.A. and Dokulil M., 2006. Macrophytes and algae in running waters. In: Ziglio G., Siligardi M. and Flaim G. (eds.), Biological Monitoring of Rivers, John Wiley \& Sons, Chichester, 89-109.

Johnson J.B. and Omland K.S., 2004. Model selection in ecology and evolution. Trends Ecol. Evol., 19, 101-108.

Lacoul P. and Freedman B., 2006. Environmental influences on aquatic plants in freshwater ecosystems. Environ. Rev., 14, 89-136.

Lambdon P.W., Pyšek P., Basnou C., Hejda M., Arianoutsou M., Essl F., Jarošík V., Pergl J., Winter M., Anastasiu P., Andriopoulos P., Bazos I., Brundu G., Celesti-Grapow L.,
Chassot P., Delipetrou P., Josefsson M., Kark S., Klotz S., Kokkoris Y., Kühn I., Marchante H., Perglová I., Pino J., Vila M., Zikos A., Roy D. and Hulme P.E., 2008. Alien flora of Europe: species diversity, temporal trends, geographical patterns and research needs. Preslia, 80, 101-149.

Linton S. and Goulder R., 2000. Botanical conservation value related to origin and management of ponds. Aquat. Conserv.: Mar. Freshwat. Ecosyst., 10, 77-91.

Marhold K. and Hindák F. (eds.), 1998. Checklist of Nonvascular and Vascular Plants of Slovakia, Veda, Bratislava, $688 \mathrm{p}$.

Mari E., Santi E., Piazzini S., Renzi M. and Maccherini S., 2010. Development of biological diversity in farmland ponds. J. Freshwat. Biol., 25, 95-105.

Markwell K.A. and Fellows C.S., 2008. Habitat and biodiversity of on-farm water storages: a case study in Southeast Queensland, Australia. Environ. Manag., 41, 234-249.

McCullagh P. and Nelder P., 1989. Generalized Linear Models, Chapman and Hall, London, 532 p.

O'Hare J.M., O'Hare M.T., Gurnell A.M., Dunbar M.J., Scarlett P.M. and Laize C., 2011. Physical constraints on the distribution of macrophytes linked with flow and sediment dynamics in British rivers. River Res. Appl., 27, 671-683.

Ot’ahel'ová H., Valachovič M. and Hrivnák R., 2007. The impact of environmental factors on the distribution pattern of aquatic plants along the Danube River corridor (Slovakia). Limnologica, 37, 290-302.

Polunin N.V.C. (ed.), 2008. Aquatic Ecosystems. Trend and Global Prospects. Cambridge University Press, Cambridge, $482 \mathrm{p}$.

R Development Core Team, 2013. R: A language and environment for statistical computing, R Foundation for Statistical Computing, Vienna, $3551 \mathrm{p}$.

Rodriguez J.B., Self J.R. and Soltanpour P.N., 1994. Optimal conditions for phosphorus analysis by the ascorbic acid-molybdenum blue method. Soil Sci. Soc. Am. J., 58, 866-870.

Sipos V.K., Kohler A., Köder M. and Janauer G.A., 2003. Macropyhte vegetation of Danube canals in Kiskunság (Hungary). Arch. Hydrobiol., 147 (Suppl. 1-2), Large Rivers 14(1-2), 143-166.

StatSoft, 2001. STATISTICA. System Reference, StatSoft Inc., Tulsa.

Willby N.J., Pygott J.R. and Eaton J.W., 2001. Interrelationships between standing crop, biodiversity and trait attributes of hydrophytic vegetation in artificial waterways. Freshwat. Biol., 46, 883-902.

Williams P., Whitfield M., Biggs J., Bray S., Fox G., Nicolet P. and Sear D., 2004. Comparative biodiversity of rivers, streams, ditches and ponds in an agricultural landscape in Southern England. Biol. Conserv., 115, 329-341. 
Appendix 1. Percentage frequency of recorded plant taxa in particular regions and habitats.

Table A1. Endangered plant taxa are bolded.

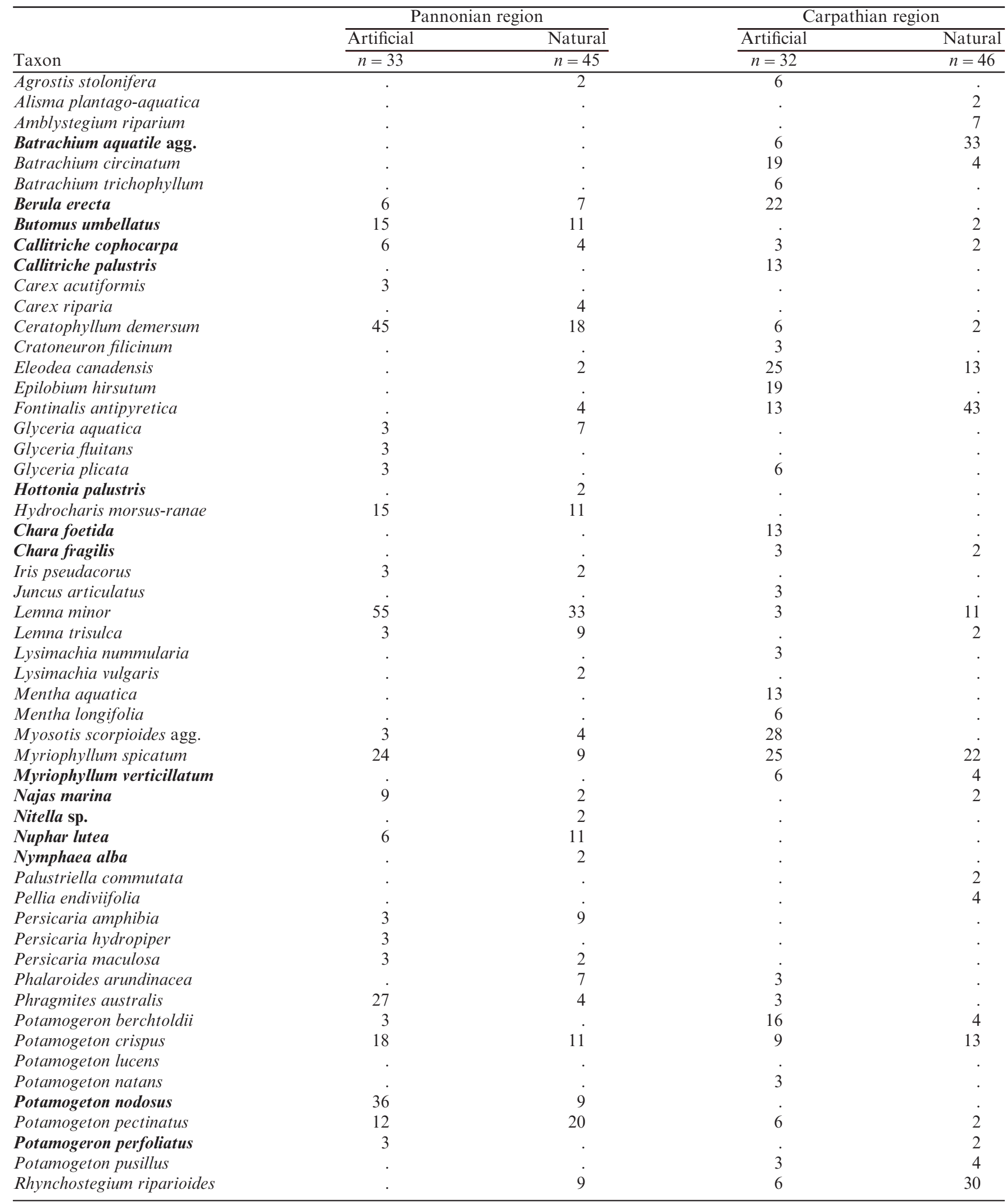


Table A1. (Contd.)

\begin{tabular}{|c|c|c|c|c|}
\hline$\overline{\text { Riccia fluitans }}$ & . & 2 & . & 2 \\
\hline Rorippa amphibia & 6 & 4 & . & . \\
\hline Rumex hydrolapathum & 3 & 4 & . & . \\
\hline Sagittaria sagittifolia & 12 & 2 & . & . \\
\hline Scrophularia umbrosa & 3 & . & 13 & . \\
\hline Solanum dulcamara & 6 & 2 & . & . \\
\hline Sparganium emersum & 15 & 13 & 9 & 4 \\
\hline Sparganium erectum & 12 & 11 & 22 & 7 \\
\hline Spirodella polyrhiza & 27 & 18 & . & . \\
\hline Trapa natans & . & 2 & . & . \\
\hline Typha angustifolia & 12 & . & . & . \\
\hline Typha latifolia & 12 & 2 & 9 & 4 \\
\hline Utricularia australis & 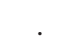 & 4 & 9 & 2 \\
\hline Veronica anagallis-aquatica & 6 & 4 & 19 & 2 \\
\hline Veronica beccabunga & 3 & 2 & 6 & 7 \\
\hline Zanichellia palustris & . & . & 3 & 4 \\
\hline
\end{tabular}

